\title{
Severe Neutrophilic Asthma: Pathogenesis and Treatment
}

\author{
Nightingale Syabbalo \\ Professor of Physiology and Medicine, Nabanji Medical Centre, Lusaka, ZAMBIA.
}

Corresponding Author: Nightingale Syabbalo, Professor of Physiology and Medicine, Nabanji Medical Centre, Lusaka, ZAMBIA.

Received Date: October 25, 2021; Accepted Date: December 22, 2021; Published Date: January 03, 2022

Citation: Nightingale Syabbalo (2022). Severe Neutrophilic Asthma: Pathogenesis and Treatment. J Thoracic Disease and Cardiothoracic Surgery, 3(1); DOI:10.31579/2693-2156/030

Copyright: (C) 2022, Nightingale Syabbalo. This is an open access article distributed under the Creative Commons Attribution License, which permits unrestricted use, distribution, and reproduction in any medium, provided the original work is properly cited.

\begin{abstract}
Asthma is a common chronic airway disease affecting about 358 million people worldwide, and an estimated 7 million children globally. Approximately $10 \%$ of patients with asthma have severe refractory disease, which is difficult to control on high doses of inhaled corticosteroids and other modifiers. Among these, are patients with severe neutrophilic asthma. Neutrophilic asthma is a severe phenotype of asthma, characterized by frequent exacerbations, persistent airway obstruction, and poor lung function. Immunopathologically, it is characterized by the presence of high levels of neutrophils in the airways and lungs. Interleukin-17 produced by Th17 cells, plays a key role in the pathogenesis of neutrophilic asthma by expressing the secretion of chemoattractant cytokines and chemokines for the recruitment, and activation of neutrophils. Interleukin- 8 is a powerful chemoattractant and activator of neutrophils. Activated neutrophils produce an oxidative burst, releasing multiple reactive oxygen species, proteinases, cytokines, which cause airway epithelial cell injury, inflammation, airway hyperresponsiveness, and remodeling. Furthermore, exasperated neutrophils due to viral, bacterial or fungal infections, and chemical irritants can release extracellular nucleic acids (DNA), designated as NETs (neutrophil extracellular traps), which are more toxic to the airway epithelial cells, and orchestrate airway inflammation, and release alarmin cytokines. Dysregulated NETs formation is associated with severe asthma. Most patients with neutrophilic asthma are unresponsive to the standard of care, including high dose inhaled corticosteroids, and to targeted biologics, such as mepolizumab, and dupilumab, which are very effective in treating eosinophilic asthma. There is unmet need to explore for novel biologics for the treatment of neutrophilic asthma, and in refining therapies, such as bronchial thermoplasty.
\end{abstract}

Key words: neutrophilic asthma; cytokines; interleukin-17; monoclonal antibodies; bronchial thermoplasty

\section{Introduction}

Asthma is a significant public health problem, affecting more than 358 million people worldwide [1], and its prevalence has been increasing during the last 40 years [2,3]. It is the most common childhood chronic respiratory disease affecting about 7 million children [4].

Asthma is a complex heterogenous chronic airway disease with several distinct phenotypes characterized by different immunopathological pathways, clinical presentation, physiology, comorbidities, biomarker of allergic inflammation, and response to treatment. It has now become clinical practice to phenotype asthma for precision and targeted treatment, because asthmatic patients respond to the standard of care (SoC) treatment differently $[5,6]$.

Asthma is classified into four distinct phenotypes based on quantitative induced sputum cytology [7-9]. The four phenotypes of asthma include eosinophilic asthma, neutrophilic asthma, paucigranulocytic asthma, and mixed cellularity asthma $[9,10]$. Patients with eosinophilic asthma have an eosinophil count of $2 \%$ to $3 \%$ [11-13], whereas patients with neutrophilic asthma have elevated sputum neutrophil count between $\geq 61 \%$ [11] and $\geq 65 \%$ [12-14], depending on the study. Mixed cellularity phenotype is characterized by increase in both eosinophils $(>3 \%)$, and neutrophils $(>61 \%$ or $\geq 65 \%$ ) [14-16]. Paucigranuocytic phenotype embraces patients with very low eosinophil numbers $(<3 \%)$, and low neutrophils count $(<61 \%$ or $<65 \%)$ in induced sputum [14,17]. Noneosinophilic asthma is the term designated to classify patients with low eosinophil counts $(<3 \%)$, which include neutrophilic asthma, and paucigranulocytic phenotype [17,18]. Asthma can also be classified as type 2-high and type 2-low, depending on biomarkers of eosinophilic inflammation, and instigating cytokines. Type 2-high is associated with eosinophilic Th2-driven asthma, whereas type 2-low represents noneosinophilic asthma [15,19].

The pathogenesis of neutrophilic asthma is multifaceted and is not fully understood; however, approximately $30 \%-50 \%$ of the patients with symptomatic asthma have the neutrophilic phenotype [5]. Neutrophilic asthma is characterized by very severe refractory disease [20-24], and persistent airway obstruction [8,25-27], frequent exacerbations, hospitalizations, emergency room visits [20], and status astmaticus [21]. Furthermore patients with neutrophilic asthma have poor response to SoC 
treatment, such as inhaled corticosteroids (ICSs), long-acting $\beta 2$-agonists (LABA), and leukotriene receptor antagonists (LTRA) [28-33]. Furthermore, neutrophilic asthma is frequently associated with steroidresistant asthma. Several cytokines incriminated in the pathogenesis of neutrophilic asthma, such as interleukin-17 (IL-17) [32,34], IL-8 [35], and tumour necrosis factor- $\alpha$ (TNF- $\alpha)$ [36] play an important role in the induction of steroid resistance.

Interleukin-17 plays a key role in the pathogenesis of neutrophilic asthma, by expressing the induction of cytokines, chemokines, and adhesion molecules which are responsible for the recruitment, and activation of neutrophils. Interleukin 8 is a very potent chemoattractant and activator of neutrophils, signaling via its receptors, CXCR1, and CXCR2. Activated neutrophils degranulate and secrete reactive oxygen species (ROS), proteases, matrix metalloproteinases, metaloperoxidases, and cytokines, which cause epithelial cells injury, inflammation, and airway hyperresponsiveness (AHR). Airway epithelial injury, and dysfunction release alarmin cytokines, such as IL-25, IL-33, and thymic stromal lymphopoietin (TSLP); and chemokines, which further orchestrates airway inflammation, AHR, and airway remodeling.

Airway remodeling in asthma is a complex progressive process involving structural changes, leading to airway narrowing, increased airflow resistance, and severe asthma. Airway remodeling includes epithelialmesenchymal transition (EMT), fibroblast and myofibloblast proliferation, deposition of extracellular matrix protein, subepithelial fibrosis, goblet cells metaplasia, airway smooth muscle (ASM) cells hyperplasia and hypertrophy, and angiogenesis [37]. Such structural changes require innovative therapies such as bronchial thermoplasty to trim the hypertrophied ASM mass, and subepithelial fibrosis.

\section{Neutrophils in Neutrophilic Asthma}

Neutrophils are polymorphonuclear leukocytes that have a fundamental role to play in innate immune response $[38,39]$. Neutrophils act as the first line of defense against pathogens, such as bacteria, fungi and perhaps viruses, and participate in the resolution of inflammation [40]. However, neutrophils also contribute to immunopathology of many diseases, including respiratory diseases, such as cystic fibrosis, bronchiectasis, acute respiratory distress syndrome (ARDS), chronic obstructive pulmonary disease (COPD), and neutrophilic asthma [38,41].

Activated neutrophils produce an NADPH oxidative burst, releasing multiple reactive oxygen species, proteases, matrix metalloproteases, myeloperoxidases, cytokines, chemokines, and lipid mediators which lead to airway inflammation, AHR, and airway remodeling. Additionally, the inflammatory mediators are responsible for airway epithelial injury, which result in the release of alarmin cytokines by epithelial cells; and mucus hypersecretion [41]. The chemoattractant mediators, such as CXCL1, CXCL6, CXCL8 (IL-8), LTB4, PAF, and thromboxanes further enhances neutrophil recruitment, migration and activation, thus amplifying the neutrophilic airway inflammation [42].

Neutrophils produce reactive oxygen species (ROS), such as superoxide anion (superoxide radical $\mathrm{O}^{-}$), hydrogen peroxide ( $\mathrm{H} 2 \mathrm{O} 2$ ), and Hypochlorous acid ( $\mathrm{HOCl})$, which lead to an increase in transcription of IL-8 by epithelial cells, further propagating the chemoattractant neutrophilic response [43,44]. Additionally, ROS synergize with neutrophil proteases to cause severe tissue damage by inactivating the actions of antiproteases [44].

Several studies have reported increased concentrations of neutrophil active mediators, such as IL-8, neutrophil elastase, matrix metalloproteinase-9 (MMP-9), leukotriene B4 (LTB4), IL-17A, GMCSF, and TNF- $\alpha$ in plasma, BAL fluid, and bronchial epithelialconditioned media derived from patients with severe neutrophilic asthma [45-49]. Grunell et al. [49] have demonstrated that children with neutrophil-predominant asthma have proinflammatory neutrophils with enhanced survival. The BAL fluid from these children demonstrates quantitatively increased levels of cytokines (IL-1 $\beta$, IL-6, IL-8); chemokines (CXCL2, CXCL3, and CXCL4); myeloperoxidase; and neutrophil elastase.

The most important proteases secreted by neutrophils during neutrophilic airway inflammation include neutrophil elastase, cathepsin G, and metalloproteases (MMP), especially MMP-9.

\section{Metalloproteases}

Metalloprotease-9 is one of the most studies inflammatory mediators in asthma. Elevated levels of MMP-9 have been found in sputum and BAL fluid from patients with asthma, and the levels correlated with neutrophil numbers [50], and the severity of asthma [51]. Wenzel et al, [52] have suggested that localized tissue MMP-9 deposition in the lungs may lead to subepithelial basement membrane thickening, fixed airflow obstruction, and severe asthma.

\section{Neutrophil Elastase}

Neutrophil elastase is one of the most cytotoxic proteins produced by activated neutrophils form the primary granules. It has been implicated in all the pathophysiological aspects of severe neutrophilic asthma. The immunopathological roles of elastase include airway epithelial injury, increased vascular permeability, hyperplasia of bronchial submucosal glands and mucus hypersecretion, bronchoconstriction, and airway hyperresponsiveness [53]. Neutrophil elastase can induce goblet cell metaplasia, mucus secretion a hallmark of severe asthma [54]. It can also induce airway smooth muscle proliferation [55], and has been implicated in airway remodeling, leading to severe airway narrowing, and progressive decline in lung function [56].

Neutrophil proteases, such as elastase, cathepsin G, and proteanase-3 may induce airway inflammation through activation of eosinophils to produce cytotoxic cationic proteins, ROS, lipid mediators, cytokines, and chemokines [57], thus aggravating neutrophilic asthma [58]. Thus, during neutrophilic asthma, there is collaborative cross-talk between neutrophils and eosinophils, leading to severe neutrophilic airway inflammation.

Neutrophil elastase levels have been reported to be elevated in bronchial secretions, and in induced sputum in asthmatic patients compared to healthy controls, especially during exacerbations $[59,60]$.

\section{Myeloperoxidase}

Myeloperoxidase (MPO) released from neutrophil primary granules can react with hydrogen peroxide generated during a respiratory burst, and produce hypochlorous acid, and other reactive oxygen species [60]. The ROS are crucial for microbial activity and antigen presentation, but play deleterious role in causing injury to lung tissue during neutrophilic inflammatory process [1]. MPO levels have been shown to be elevated in the BAL fluid of patients with asthma compared to normal subjects [60]

\section{Lipid Mediators}

Neutrophils can synthesize lipid mediators such as and leukotrienes (LTB4) and platelet activating factor (PAF). They are also able to produce prostaglandins (PGE2) and thomboxanes (TBXA2) via cyclooxygenase 
enzyme systems [61,62]. Lipid mediators play an important role in neutrophil migration, and activation in the airway inflammation process.

\section{Reactive Oxygen Species}

Activated neutrophils are the major source of reactive oxygen species (ROS), such as hydrogen peroxide, hypochlorous acid, and superoxide radical $\left(\mathrm{O}^{-}\right)$in allergic inflammation. ROS act synergistically with neutrophil proteases to cause lung tissue damage, submucosal glands hyperplasia and mucus secretion, and airway hyperreactivity [56,63,64].

In vitro stimulation of neutrophils from atopic asthmatic patients with inophore A2318, and the chemoattractant fMLP have been shown to produce higher level of ROS compared to non-atopic subjects [65,66]. Tanazawa et al. [66] have reported that the production of free oxygen radicals was inversely proportional to measures of airway obstruction, e.g., FEV1. Furthermore, higher levels of O2- have been reported during asthma attacks and exacerbations compared to levels in stable asthma [64]. Thus implicating ROS in the pathogenesis of severe neutrophilic asthma, and in promoting exacerbations. Loukides and colleagues have reported an increase in hydrogen peroxide in expired breath condensate from patients with asthma, which correlated with airway inflammation, and asthma severity [67].

Table 1 shows neutrophil-derived antimicrobials and inflammatory mediators, including cytoplasts, and Table 2 lists mediators associated with neutrophilic airway inflammation.

\section{Neutrophil Extracellular Traps}

Neutrophils play a sentinel role by safeguarding the host immune homeostasis through maintaining a strict equilibrium of the innate immunity, and acute inflammatory responses [68]. Neutrophils' defense against invading microbes include phagocytosis, degranulation, and NADPH oxidative burst [69]. However, neutrophils can extrude cytosolic, and nuclear material via a conservative cell death process distinct from apoptosis and necrosis, which can be more lethal to the invading microbes. Chemical-induced neutrophil autotoxicity has been known for over 2 decades, although its clinical significance was less clear [70,71]. Exasperated neutrophils due to viral, bacterial or fungal infections, and chemical irritants can release extracellular nucleic acids (DNA), designated as NETS (neutrophil extracellular traps) [72]. The term NET was first coined by Brinkmann and colleagues in 2004, as a novel antimicrobial defense system [73]. NETs are web-like scaffolds of extracellular DNA complex with histones, and antimicrobial neutrophil granular proteins, such as neutrophil elastase, and myeloperoxidase. NETosis can generate enucluated "'ghost" neutrophils with chemokinesis, termed cytoplasts which are also toxic to the airway epithelial cells, and exogenous bacteria [74]. Furthemore, nefarious neutrophil cytoplast formation in asthmatic lung inflammation is linked to Th17-mediated neutrophilic inflammation in severe asthma [75].

NETosis or neutrophil suicide was first described following chemical stimulation with phorbol 12-myristate 13-acetate (PMA) [71]. NETosis was further elucidated by Takei et al. [72], who demonstrated that PMAinduced suicide resulted in the release of a novel defense structure, named NET [72].

NETs release or NETosis is an NADPH oxidative-dependent cellular death requiring chromatin decondensation [76]. It is an orderly suicide, which involves nucleus envelop fragmentation, and mixing of nucleic acids and granule proteins with in a large vacuole. Finally, after intracellular assembly NETs are release via perforations in the cell membrane, and cell lysis. Once released, the DNA structures entrap both gram-negative and gram-positive [72,73]. This form of cell death is different from apoptosis, because it a novel host defense form of beneficial suicide [77]. Entrapment of microorganisms by NETs restrict potential pathogen dissemination from the initial site of infection [78]. Eosinophils can also undergo NETosis, but eosinophil extracellular traps contain significantly less proteases than neutrophil extracellular traps, and may therefore be very stable, and cause less tissue injury [79]

Although NETs are considered an essential part of neutrophil-mediated immunity, they have also been incriminated in NET-based immunopathology [80,81]. NETosis may represent a "double-edged sword" in innate immunity [82]. Abnormal NET production in the circulation and tissues have been demonstrated in patients with cystic fibrosis, and ARDS [83-85]. These are airways diseases characterized by mucosal neutrophilic inflammation. Additionally, NETs can directly trigger epithelial cell death [86], or may impair lung epithelial barrier function during respiratory viral infection in vivo [87]. Furthermore, murine studied have shown an important role for NETs in inducing airway mucus hypersecretion [88].

Dysregulation of NETs formation may play a critical role in the pathogenesis of chronic airways diseases, such as chronic obstructive pulmonary disease (COPD) [89-92], and asthma [23]. Furthermore, neutrophil autophagy and extracellular DNA traps contribute to airway inflammation, and severe asthma [93]. Similarly, Dicker and colleagues have reported that NET formation in the airways of patients with COPD was associated with disease severity [94].

There is concrete evidence that respiratory virus infection (Rhinovirus) [95,96], bacterial infection (Staphylococcus aureus) [97], and pulmonary fungal infection (Aspergillus fumigatus) [98,99], can induce NETs production. Furthermore, Toussaint et al. [95] have hypothesized that the release of NETs containing DNA may exacerbate airway inflammation, indicating that NETs may be responsible for severe asthma exacerbations. Similarly, Lachowicz-Scroggins and colleagues have shown that patients with severe asthma have significantly higher levels of extracellular DNA compared with healthy controls [100].

\section{INTERLEUKIN-17}

Interleukin-17A (thereafter, synonymously called IL-17) was initially identified as cytotoxic T-lymphocyte-associated antigen 8 (CTLA-8) in 1993 by Rouvier and colleagues [101]. Subsequent characterization revealed that IL-17 was produced by a special type of $\mathrm{T}$ helper cells known as Th17 cells, and thus renamed as IL-17 [102-104]. Latter genomic sequencing led to the discovery of additional IL-17 family members totaling six, namely IL-17A (IL-17), IL-17B, IL-17C, IL-17D, IL-17E (also known as IL-25), and IL-17F [105-109]. Unlike its siblings, IL-25 is an epithelial cell-secreted cytokine, mediating Th2 eosinophilic airway inflammation, via induction of Th2 cytokines, such as IL-5, IL-4, and IL-13 [110]. The immunology of the less tweedy, orphan cytokine IL-17D is poorly understood.

IL-17 is disulfide-linked homodimeric glycoprotein consisting of 155 amino acids with a molecular weight of $35 \mathrm{kDa}$; but heterodimers composed of IL-17A and IL-17F, as well as IL-17F homodimers exist [110,111]. IL-17A homodimer produce more pathophysiologic responses that the heterodimer or the IL-17F homodimer [108,111,112]. Among the IL-17 family members, IL-17F has the highest homology (55\%) with IL17A [108,113], and IL-17E (IL-25), is the most knotty, divergent cytokine in the IL-17 family, sharing 16-20\% sequence homology with its cousins 
[108]. IL-17A and IL-17F have similar pathophysiological roles, although IL-17 is about 10-30 times as potent as IL-17F [11]. IL-17 is the founding and most studied family member [5,8], especially in the pathogenesis of rheumatoid arthritis [114-117], psoriasis [118-120], and currently in the pathogenesis of neutrophilic asthma [121,122].

Interleukin-17 is secreted mainly by a distinct CD4+ T helper 17 (Th17) cells [123-125], characterized by expression of the master transcription factor retinoic acid-related orphan-receptor- $\gamma \mathrm{t}$ (ROR $\gamma \mathrm{t}$ ) [126]. IL-17 is also secreted by other activated immune cells, such as dendritic cells, CD8+ T cells, $\delta \gamma \mathrm{T}$ cells, natural killer cells, invariant natural killer T cells, lymphoid tissue inducer cells, and type 3 innate lymphoid cells [127-132].

Several studies have reported increased levels of IL-17 in sputum and BAL fluid [133-135], and a positive correlation between IL-17 concentration and severity of asthma $[134,135]$. Similarly, Bullens et al. [136] have shown an increase in IL-17 mRNA in sputum of asthmatic patients, which was linked with airway influx of granulocytes including neutrophils. Furthermore, increased IL-17 and IL-17F levels [137-139], Th17 cells [140-143], and IL-17-producing innate type 3 lymphoid cells (ILC3) [144], have been demonstrated to be increased in BAL fluid, lung biopsies, and peripheral blood in patients with severe asthma. The levels of these biomarkers of neutrophilic airway inflammation have been shown to correlate with the severity of asthma in both adults [137141,143,144], and children [142].

Interleukin-17 engenders tissue inflammation mainly by stimulating expression of several proinflammatory cytokine, such as IL-6, IL-8, and TNF- $\alpha[145,146]$, and chemokines, including CXCL1, CXCL2, CXCL5, CXCL8, and CXCL20 [145,147,148]. IL-17 also induces secretion of growth factors, such as G-CSF, and GM-CSF [145,149,150], which play very important roles in neutrophil airway immunopathology.

Interleukin-17, Airway Hyperresponsiveness and Remodeling

Interleukin-17 directly or indirectly contributes to airway hyperresponsivess, and remodeling in patients with neutrophilic asthma [151]. IL-17 contributes to the development of subepithelial fibrosis by enhancing the production of profibrotic cytokines, and activation of fibroblasts, which produces collagen [152-155]. Increased airway smooth muscle (ASM) mass is a hallmark of airway remodeling in severe asthma. IL-17 and the cytokines it induces, such as IL-6, IL-1 $\beta$, and chemokines including CXCL8/IL-8, and eotaxin, promote airway smooth muscle (ASM) cell proliferation and migration [156-158]. IL-17 also promotes ASM cell survival by inhibiting apoptosis [156-158]. Blockade of IL-17 receptors (IL-17A or IL-17C) prevents the ability of ASM cells to proliferate and migrate [158]. Additionally, IL-17 enhances ASM cell contraction. This effect is mediated by the IL-17-induced activation of the RhoA-ROCK pathway in ASM cells. This pathway is an important regulator of myosin light chain phosphorylation involved in smooth muscle contractility [159]. Increase in ASM cell mass and contractility can result into airway hyperresponsiveness, bronchoconstriction, and severe airflow limitation. Furthermore, IL-17 promotes angiogenesis, which is a hallmark of remodeling in severe asthma [160]

Airway mucus hypersecretion and mucus plugging is one of the serious complication of severe neutrophilic asthma. IL-17 is a potent secretagogue which stimulates submucosal glands and goblet cell hyperplasia, and hypersecretion of mucus. Increased mucus secretion results from increased gene expression. It has been reported to stimulate MUC5A and MUC5B gene expression in monkey and mouse tracheobronchial epithelial cells 161,162]. Noteworthy, IL-17 contributes to the development of steroid-insensitive asthma [163,164]. The pathophysiological mechanisms for severe neutrophilic asthma are outlined in Table 3.

\section{Treatment of Severe Neutrophilic Asthma}

Most patients with stable asthma respond to treatment with standard therapies, such as long-acting $\beta$-agonists (LABA), low dose inhaled corticosteriods (ICS), and leukotriene receptor antagonists (LTRA), using the stepwise guidelines. However, treatment of severe neutrophilic asthma is challenging. Unlike eosinophilic asthma, there are no specific biomarkers, such as fractional exhaled nitric oxide (FeNO), periostin, and DDP-4 to select patients who are more likely to benefit from biologics. Currently, there are also no effective biologics specifically targeting airway neutrophilic inflammation. The approved biologics by the FDA, and their dosages for the treatment of eosinophilic asthma are portrayed in Table 4.

Several clinical trials investigating the efficacy and safety of biologics targeting the incriminated cytokines and their receptors in the pathogenesis of neutrophilic asthma, such as IL-8 (CXCR1/2), and IL-17 (IL-17AR) have not been successful. Biologics targeting the IL8/CXCR1/2 axis did not meet the endpoints for the treatment of severe uncontrolled neutrophilic asthma. In a small clinical trial, the CXCR1/2 inhibitor SCH527123 significantly reduced sputum neutrophil count, but only led to a modest improvement in asthma control [165]. Similarly, in a larger multicenter study in patients with uncontrolled persistent asthma, and high blood neutrophil count, the CXCR2 antagonist AZ5069 did not reduce severe asthma exacerbations [166]. Currently, none of the IL8/CXCR1/2 axis antagonists has achieved the endpoints in the treatment of severe neutrophilic asthma

Biologics targeting IL-17 signaling, such as brodalumab [167], and secukinumab [168], have also not been successful in clinical trials. Busse at al. [167] in a randomized, placebo-controlled phase IIa trial of brodalumab, a monoclonal antibody against IL-17 receptor, in patients with moderate-to-severe asthma, reported that, brodalumab did not result in any statistically significant benefit in terms of ACQ scores, FEV1, or use of rescue short-acting $\beta$-agonists (SABA). Similarly, secukinumab failed to suppress ozone-induced airway neutrophilic inflammation in healthy volunteers [168]. The good news is that, both brodalumab (Siliq) [169], and secukinumab (Consentyx) [170], have been approved by the Food and Drug Administration for the treatment of plaque psoriasis, and ankylosing spondylitis.

\section{Macrolide Antibiotics}

Macrolide antibiotics, such as erythromycin (ERM), azithromycin (AZM), clarithromycin (CAM), and roxithromycin (RXM), and the 16membered lactone ring (spiromycin, josamycin, midecamycin), or the new ketolide antibiotic telithromycin have antiviral, antibacterial [171174], anti-inflammatory, and immunomodulatory effects [175-178].

Several studies have reported that treatment with AZM, CAM, and RXM decrease eosinophil and neutrophil counts, inhibit neutrophil migration, and oxidative burst activity and mediator release. Consequently, there is a decrease in the concentrations of neutrophil elastase, metalloproteinase9, IL-8, IL-6, IL-1 $\beta$, TNF- $\alpha$, and eosinophilic cationic protein (ECP) [178-183].

Long-term, low-dose macrolides plays an important role in the treatment of chronic inflammatory airway diseases [184,185], such as panbronchiolitis [186], cystic fibrosis [187], noncystic fibrosis bronchiectasis [188], bronchiolitis obliterans syndrome [189], post-lung transplantation bronchiolitis obliterans syndrome [190], and COPD [191]. Macrolide antibiotics have been used for the treatment of asthma since 
1970 [192], and currently, they have become very popular for the treatment of severe, uncontrolled neutrophilic asthma [193,194]. The British Thoracic Society has outlined very valuable guidelines for the use of long-term macrolides in adults with respiratory diseases, including asthma [195].

Several clinical trials have documented the efficacy and safety of longterm, low-dose macrolides in the treatment of severe asthma. Simpson, et al. [196] have shown that clarithromycin in patients with severe refractory asthma reduced neutrophil count, and sputum IL-8 levels, although they did not observe any change in lung function or asthma control [196]. The Azithromycin for prevention of exacerbations in severe asthma (AZISAST) randomized, placebo-controlled trial investigated the efficacy of azithromycin in patients with severe asthma with history of severe exacerbations, despite receiving high-dose ICS and LABA [197]. There was no effect of AZM on the primary outcome in the total population when assessed without inflammatory phenotype. However, AZM (250 mg daily three times per week) as add-on treatment in patients with nonesonophilic asthma, defined by normal blood eosinophil count, and normal FeNO, resulted in significantly fewer severe exacerbations during 26-week period compared with controls [197]. Azithromycin significantly reduced both severe exacerbations, and lower respiratory tract infection in non-eosinophilic asthma phenotype by approximately $67 \%$ compared to $38 \%$ in placebo group. Azithromycin was ineffective in eosinophilic asthma, and in fact, the eosinophilic subgroup had more exacerbations when taking AZM [26]. This underpins the importance of phenotyping in selecting patients for targeted precision therapies [193,197].

The second well conducted, randomized double-blinded, placebocontrolled trial (AMAZES) compared add-on azithromycin (500 mg three times per week) with placebo for 48 weeks in patients with symptomatic asthma despite medium-to high dose ICS and LABA [198]. Treatment with add-on azithromycin significantly reduced the incidence of medium and severe exacerbation by 1.07 versus 1.86 per person-year, for AZM and placebo, respectively. AZM treatment was also associated with an improvement in Asthma Quality of life Questionnaire (AQLQ) scores in both groups of patients with eosinophilic and noneosinophilic asthma phenotypes [198].

Similarly, the Telithromycin, Chlamydophila, and Asthma (TELICAST) multicenter, randomized, double-blind, placebo-controlled study in 278 patients with moderate-to severe asthma reported significantly greater improvement in symptoms, and lung function in patients receiving telithromycin, $800 \mathrm{mg}$ once daily, for 10 days compared with placebo [199]. Patients receiving telithromycin showed improvement in exacerbation symptoms at the end of treatment of $51 \%$ versus $29 \%$ in the placebo treated patients. There was also a significant improvement in FEV1 of $0.63 \mathrm{~L}$ in telithromycin-treated patients versus $0.29 \mathrm{~L}$ in placebotreated [199].

The Azithromycin Against Placebo in Exacerbations of Asthma (AZALEA) study investigated the effectiveness of azithromycin treatment as add-on to standard therapy for adult patients with exacerbation [200]. In the AZALEA clinical trial, addition of azithromycin $500 \mathrm{mg}$ daily for 3 days to the standard treatment resulted in no statistically significant clinical improvement, including symptoms and quality of life scores, and FEV1 [200]. This large trial in the United Kingdom had challenges in the recruitment of subjects, because there was widespread use of antibiotics in the 31 centers enrolled for the study. The study was therefore underpowered because a large number of patients (2044) were excluded, because they were already taking antibiotics for their exacerbations [200]. It is possible that the population randomized was not representative of the larger population, because more than 2000 other patients were excluded from the study for other reasons [200]. However, long-term, low-dose macrolide antibiotic therapy does clinically, and significantly reduce severe exacerbations, improve lung function, and health-related quality of life (HLQoL) in patients with neutrophilic asthma.

The outcomes of the above clinical trials, indicate that different macrolides including the dosages of the specific drugs may influence the immunomodulatory effects, and efficacy of macrolide antibiotics in patients with severe neutrophilic asthma. Phenotyping of patients, and treatment of comorbid diseases with neutrophilic asthma, such as allergic rhinitis, chronic rhinosinusitis with nasal polyps, gastroesophageal reflux disease, and obesity influence the effectiveness of macrolides [193]. Therefore, before patients are administered long-term macrolide therapy, the patients should be carefully selected; and comorbid disorders should be treated, in order to prevent unnecessary cardiotoxicities, and community-wide macrolide resistance.

\section{Bronchial Thermoplasty}

Bronchial thermoplasty (BT) is a novel bronchoscopic therapy aimed at reducing the hypertrophied ASM mass in patients with severe refractory asthma [201-203]. BT is approved for subjects aged 18 and above with severe persistent asthma not responding to high-dose ICS, LABA, and eosinophilic interleukin antagonists. It is suitable for all the phenotypes of asthma characterized by ASM hypertrophy, and severe airway remodeling [204-209], insensitive to eosinophilic biologics, such as neutrophilic, and paucigranulocytic asthma [208,209].

Bronchial thermoplasty is a complex procedure, and should be performed in highly specialized centers. Performance of BT requires bronchoscopic meticulousness, dexterity, and good knowledge of the airway anatomy [210]. The selection and preparation of patients for BT is rigorous, and the procedure should be performed by experienced pulmonologists or bronchoscopists [205,206,210]. Patients for bronchial thermoplasty should be in an optimal stable condition, and selection of patients for BT is critical. In addition to their standard medical treatment for severe asthma, patients should be pre-treated with prednisolone $50 \mathrm{mg} /$ day for 3 days before BT, one day before BT, on the day of BT, and the day after bronchial thermoplasty [206]. Before the procedure, patients should be pre-treated with nebulized salbutamol and/or ipratropium bromide [206].

Bronchial thermoplasty is performed under moderate-to-deep sedation or general anesthesia [205-210]. At bronchoscopy a special disposable Alair $^{\mathrm{TM}}$ catheter (Boston Scientific, Marlborough, MA, USA) with a distal diameter of $1.4 \mathrm{~mm}$, and a basket-like array of expandable electrodes is inserted through the instrument channel [211]. Optimal thermoplasty of all subsegment bronchi is successful with ultrathin, rotatable bronchoscopes with increased ease of use and higher degree of flexibility [206]. BT trims excessive hypertrophied ASM mass, submucosal glands [201-203,208,212,213], collagen deposition [2013], epithelial cells, and neuroendocrine cells [214], and hyperreactive cholinergic nerves [215]. Thus, reducing all the structural changes involved in AHR, airway remodeling, and severe neutrophilic asthma. Noteworthy, BT promotes regeneration of epithelial cells [214], and persistently reduces mucin production after bronchial thermoplasty [216]. Bronchial thermoplasty also reduces regeneration of ASM cells, and decreases (Ki67+) subepithelial cells proliferation [17]. Furthermore, BT increases the expression and activation of glucocorticoid receptors (GR) in airway epithelial cells, and subepithelial mesenchymal cells [218], and probably restores steroid-sensitivity. 
Post-bronchial thermoplasty care should be optimized, because BTassociated adverse effects usually occur during the first 30 days after the procedure. Post-BT adverse events (Table 4) should not scare anyone, because bronchial thermoplasty has been demonstrated to be safe and well tolerated in experienced hands.

Several clinical trials have reported the efficacy and safety of bronchial thermoplasty. Most studies have reported that BT improves asthma symptoms, reduces exacerbations, hospitalizations, and emergency department visits [201,208-213]. Additionally, BT improves asthma quality of life questionnaire (AQLQ) scores, lung function [201,219,220], and allows patients to wean or discontinue corticosteroids [219].

The beneficial effects of BT are durable and can last up to 3-5 years [207,221-224]. At 5 years patients still have stable lung function, and lack of increase in hospital admission, and emergence department visits [220223]. Furthermore, BT has been reported to be still effective after 10 years of the procedure. The preliminary findings were that the AQLQ scores, and severe exacerbation rates were comparable to those recorded 1 year after bronchial thermoplasty [225]. Refinement in the technique is in progress, and more patients with severe refractory asthma will cherish thermoplasty.

\section{Conclusion}

Neutrohilic asthma is a severe phenotype of asthma characterized by persistent airway obstruction, and poor lung function. Interleukin-17, and its subordinate cytokine IL- 8 play a key role in the pathogenesis of neutrophilic asthma, The dual cytokines promote trafficking, activation, and degranulation of neutrophil in the airways, which result in secretions of reactive oxygen species, proteases, cytokine, chemokines, and growth factors. These pro-inflammatory mediators propagate airway inflammation, AHR, and airway remodeling. Treatment of severe neutrophilic asthma is challenging, because it does not respond to Th2 eosininophilic biologics, such as mepolizumab, and dupilumab; and targeting IL-17, IL-8 and their receptors has been unsuccessful, and fruitless. Macrolide antibiotics have immunomodulatory effects, and some patients with neutrophilic asthma respond to long-term, low-dose macrolide therapy. Bronchial thermoplasty is an innovative bronchoscopy procedure aimed at reducing the hypertrophied ASM mass. BT has been shown to improves asthma symptoms, reduce exacerbations, hospitalizations, and emergency department visits. Additionally, BT improves AQLQ scores, lung function, and allows patients to taper or discontinue corticosteroids. The therapeutic effects of BT can last for more than 5 years.

\section{Conflict of interest}

The author declares that the publication was conducted in the absence of any commercial or financial relationships that could be construed as a potential conflict of interest.

ORCID ID: https://orcid.org/0000-0002-9435-5456

\section{References}

1. GBD (2015). Chronic Respiratory Disease Collaborators. Global, regional, and national deaths, prevalence, disability adjusted life years, and years lived with disability for chronic obstructive pulmonary disease and asthma, 1990-2015: a systemic analysis for the Global Burden of Disease Study 2015. Lancet Respir Med 2017; 5(9):691-706.

2. Global Initiative for Asthma. Global Strategy for Asthma management and Prevention, [updated 2018].
3. The Global Asthma Network. The Global Asthma Report 2014.

4. Asher I, Pearce N. (2014). Global burden of asthma among children. Int J Tuberc Lung Dis 2014; 18:1269-1278.

5. Chung KF. (2016). Asthma phenotyping: A necessity for improved therapeutic precision and new targeted therapies. J Intern Med 2016; 279:192-204.

6. Svenningsen S, Nair P. (2017). Asthma endotypes and an overview of targeted therapy for asthma. Front Med (Lausanne) 2017; 4:158.

7. Wenzel SE, Schwartz LB, Langmack EL, Halliday JL, Trudeau JB, Gibbs RL. (1999). Evidence that severe asthma can be divided pathologically into two inflammatory subtypes with distinct physiologic and clinical characteristics. Am J Respir Crit Care Med 1999; 160: 1001-1008.

8. Simpson JL, Scott R, Boyle MJ, Gibson PG. (2006). Inflammatory subtypes in asthma: assessment and identification using induced sputum. Respirology 2006; 11(1): 54-61.

9. Wang F, He XY, Baines KJ, Gunawardhana LP, Simpson JL, Gibson PG. (2011). Different inflammatory phenotypes in adults and children with acute asthma. Eur Respir J 2011; 38:567-574.

10. Syabbalo N. (2020). Clinical features and management of eosinophilic asthma. J Respir Dis Treat 2020; 1:105.

11. Aleman F, Lim HF, Nair P. (2016). Eosinophilic endotype of asthma. Immunol Allergy North Am 2016; 36(3): 559-568.

12. Arron JR, Choy DF, Scheerens H, Mathews JG. (2013). Noninvasive biomarkers that predict treatment benefit from biologic therapies in asthma. Ann Am Thorac Soc 2013; 10:S206-S213.

13. Berry M, Morgan A, Shaw DE, Parker D, Green D, Brightling C, et al. (2007). Pathological features and inhaled corticosteroid response of eosinophilic and non-eosinophilic asthma. Thorax 2007; 62:1043-1049.

14. Nair P, Aziz-Ur-Rehman A, Radford K. (2015). Therapeutic implication of 'neutrophilic asthma'. Curr Opin Pulm Med 2015; 21(1):33-38.

15. Ray A, Kolls JK. (2017). Neutrophilic inflammation in asthma is associated with disease severity. Trends Immunol 2017; 38(12):942-954.

16. Svenningsen S, Nair P. (2017). Asthma endotypes and an overview of targeted therapy for asthma. Front Med (Lausanne) 2017; 4:158.

17. Syabbalo N. (2020). Clinical features and management of paucigranulocytic asthma. Ann Clin Med Res 2020; 1(3):1011.

18. Thomson N. (2016). Novel approaches to the management of noneosinophilic asthma. Ther Adv Respir Dis 2016; 10(3):211234.

19. Israel E, Reddel HK. (2017). Severe and difficult-to-treat asthma in adults. N Engl J med 2017; 377:965-976.

20. Fahy JV, Kim KW, Liu J, Boushey HA. (1995). Prominent neutrophilic inflammation in sputum from subjects with recurrent asthma exacerbations. J Allergy Clin Immunol 1995; 95:843-852.

21. Lamblin C, Gosset P, Tillie-Leblond I, et al. (1998). Bronchial neutrophilia in patients with noninfectious status asthmaticus. Am J Respiratory Crit Care Med 1998; 157:394-402.

22. Jatakanon A, Ausuf C, Maziak W, Lim S, Chung KF, Barnes PJ. (1999). Neutrophilic inflammation in severe persistent asthma. Am J Respir Crit Care Med 1999; 160:1532-1539.

23. Ordonez CL, Shaughnessy TE, Matthay MA, Fahy JV. (2000). Increased neutrophil numbers and IL-8 levels in airway secretions in acute asthma: clinical and biologic significance. Am J Respir Crit Care Med 161:1185-1190. 
24. Macedo P, Hew M, Torrego A, et al. (2009). Inflammatory biomarkers in airways of patients with severe asthma compared with non-severe asthma. Clin Exp Allergy 39:1668-1676.

25. Woodruff PG, Khashayar R, Lazarus SC, et al. (2001). Relationship between airway inflammation, hyperresponsiveness, and obstruction in asthma. J Allergy Clin Immunol 108:753-758.

26. Baines KJ, Simpson JL, Wood LG, Scott RJ, Gibson PG. (2011). Transcriptional phenotypes of asthma defined by gene expression profiling of induced sputum samples. J Allergy Clin Immunol 127:160.e1-e9.

27. Shaw DE, Berry MA, Hargadon B, et al. (2006). Association between neutrophil airway inflammation and airflow limitation in adults with asthma. Chest 132:1871-1875.

28. Holgate ST, Polosa R. The mechanisms, diagnosis, and management of severe asthma in dults. 368:780-793.

29. Moore W, Bleecker E, Curren-Everett D, Erzurum S, Ameredes BT, Bachier L, et al. (2007). National Heart, Lung, and Blood Institute's Severe Asthma Research Program. Characterization of the severe asthma phenotypes by the National Heart, Lung, and Blood Institute's Severe Asthma Research Program. $J$ Allergy Clin Immunol 119:405-413.

30. Bel EH, Sousa A, Fleming L, Bush A, et al. (2011). Diagnosis of severe refractory asthma: an international consensus statement from the Innovative Medicine Initiative (AMI). Thorax 66:910-917.

31. Wener RL, Bel EH. (2013). Severe refractory asthma: an update. Eur Respir Rev 22:196-201.

32. Chambers ES, Nanzer AM, Pfeffer PE, Richards DF, Timms PM, Martneau AR, Griffiths CJ, Corrigan CJ, Hawrylowicz CM. (2015). Distinct endotypes of steroid-resistant asthma characterized by IL-17A and IFN- $\gamma$ high immunophenotypes: potential benefit of calcitriol. J Allergy Clin Immunol 136:628637.e4.

33. Nabe K. Steroid-resistant asthma and neutrophils. J-STAGE 2020; 4391):31-35.

34. McKinley L, Alcorn JF, Peterson A, Dupont RB, Kapadia S, Logar A, Henry A, Irvin CG, Piganelli JD, Ray A, Kolls JK. (2008) TH17 cells mediate steroid-resistant airway inflammation and airway hyperresponsiveness in mice. $J$ Immunol 181:4089-4097.

35. Liu R, Bai J, Xu G, Xuan L, Zhang T, Meng A, Hou Q. (2013) Multi-allergen challenge stimulates steroid-resistant airway inflammation via NK-kB-mediated IL-8 expression. Inflammation 36:845-854.

36. Howarth PH, Babu KS, Al Ali M, Chauhan A, et al. (2005) Tumour necrosis factor (TNF-alpha) as a novel therapeutic target in symptomatic corticosteroid dependent asthma. Thorax; 60:1012-1018.

37. Syabbalo N. The role of airway remodeling in the pathophysiology and treatment of severe asthma. J Online Med Biol. 2021; 1(1):1002.

38. Summers C, Ranklin SM, Condliffe AM, Singh N, Peters AM, Chilvers ER. Neutrophil kinetics in health and disease. Trends Immunol 2010; 31:318-324.

39. Bruijnzeel PLB, Uddin M, Koenderman L. Targeting neutrophilic inflammation in severe neutrophilic asthma: can we target the disease-relevant neutrophil phenotype. J Leukoc Biol 2015:98:549-556.

40. Naeseef WM, Borragaard N. Neutrophils at work. Nat Immunol 2014; 15:602-611.

41. Woodruff PG, Fahy JV. A role for neutrophil in asthma. Am J Med 2002; 112(6):498-500.
42. Nakagome K, Matsushita S, Nagata M. Neutrophil inflammation in severe asthma. Int Arch Allergy 2012; 158(Suppl 1):96-102.

43. Lindén A. Role of interleukin-17 and the neutrophil in asthma In Arch Allergy Immunol 2001; 126:179-184.

44. Kato M, Nakano M, Morikawa A, Kimura H, Shigeta K, Kurume T. Ability of polymorphonuclear leukocytes to generate active oxygen species in children with bronchial asthma. In Arch Allergy Immunol 1991; 95:17-22.

45. Teran LM, Campos MG, Begishvilli BT, Schröder JM, Djukanovic R, Shute JK, Church MK, Holgate ST, Davies DE. Identification of neutrophil chemotactic factors in bronchoalveolar lavage fluid of asthmatic patients. Clin Exp Allergy 1997; 27:396-405.

46. Wenzel SE, Larsen GL, Johnston K, Voelkel NF, Westcott JY. Elevated levels of leukotriene $\mathrm{C} 4$ in brronchoalveolar lavage fluid from atopic asthmatics after endobronchial allergen challenge. Am Rev Respir Dis 1990; 142:112-119.

47. Brown PH, Crompton GK, Greening AP. Proinflammatory cytokines in asthma. Lancet 1991; 338:590-593.

48. Howarth PH, Babu KS, Arshad HS, Lau L, Buckley M, McConnell W, Beckett P, et al. Tumour necrosis factor (TNF $\alpha$ ) as a novel therapeutic target in symptomatic corticosteroid dependent asthma. Thorax 2005; 60:1012-1018.

49. Grunwell JR, Stephenson ST, Tirouvanzian R, Brown LAS, Fitzpatrick AM. Children with neutrophilic predominant severe asthma have proinflammatory neutrophils with enhanced survival and impaired survival. J Allergy Clin Immunol 2019; 7:516-525

50. Cundall M, Sun Y, Miranda C, Trudeau JB, Barnes S, Wenzel SE. Neutrophil-derived metalloproteinase- 9 is increased in severe asthma and poorly inhibited by glucocorticoids. J Allergy Clin Immunol 2003; 112(6):1064-1071.

51. Hoshino M, Nakamura Y, Sim J, Shimojo J, Isogai S. Bronchial subepithelial fibrosis and expression of metalloproteinase-9 in asthmatic airway inflammation. J Allergy Clin Immunol 1998; 102:783-788.

52. Wenzel SE, Balzar S, Cundall M, Chu HW. Subepithelial basement membrane immunoreactivity for metalloprotease-9: association with asthma severity, neutrophilic inflammation, and wound repair. J Allergy Clin Immunol 2003; 111(3):13451352.

53. Amitani R, Wilson R, Rutman A, Read R, Ward C, Burnett D, Stockley RA, Cole PJ. Effects of human neutrophil elastase and Pseudomonas aeruginosa proteases on human respiratory epithelium. Am J Respir Cell Mol Biol 1999; 4:26-32.

54. Nadel JA. Role of enzymes from inflammatory cells on submucosal gland secretion. Respiration 1991; 58:3-5.

55. Vargas A, Roux-Dalvai F, Droit A, Lavoie JP. Neutrophilderived exosomes: a new mechanism contributing to airway smooth muscle remodeling. Am J Respir Cell Mol Biol 2016; 55(3):450-456.

56. Nadel JA. Role of neutrophil elastase in hypersecretion during COPD exacerbations, and proposed therapies. Chest 2000; 117(5 Suppl 2):386S-389S.

57. Hogan SP, Rosenberg HF, Moqbel R, Phipps S, Foster PS, Lacy P, Kay AB, Rothenberg ME. Eosinophils: biological properties and roles in health and disease. Clin Exp Allergy 2008; 38(5):709-750.

58. Hiraguchi Y Nagao M, Hosoki K, Okuda R, Fujisawa T. Neutrophil proteases activate eosinophil function in vitro. In Arch Allergy Immunol 2008; 146(Suppl 1):16-21.

59. Monteseirín J, Bonella I, Camacho MJ, Chacón P, Vega A, Chaparro A, Conde J, Sobrino F. Specific allergens enhance 
elastase release in stimulated neutrophils from asthma patients. Int Arch Allergy Immunol 2003; 131:174-181.

60. Monteseirín J. Neutrophil in asthma. J Investig Allergol Clin Immunol 2009; 19(5):340-354.

61. Chabanne SB, Hosni R, Moliere P, Croset M, Pacheco Y, Perrin-Fayole M, Lagarde M. Leukotriene B4 levels in neutrophils from allergic and healthy subjects stimulated by low concentration of calcium ionophore A23187. Effect of exogenous arachidonic acid and possible endogenous source. Biochim Biophys Acta 1991; 1093:47-54.

62. Maloney CG, Kutchara WA, Albertine KH, McIntyre TM, Prescott SM, Zimmerman GA. Inflammatory agonist induce cyclooxygenase type 2 expression by human neutrophils. J Immunol 1998; 160:1402-1410.

63. Kato M, Nakano M, Morikawe A, Kimura H, Shigata M, Kurume T. Ability of polymorphonuclear leukocytes to generate active oxygen species in children with bronchial asthma. Int Arch Allergy Appl Immunol 1991; 95:17-22.

64. Styrt B, Rockling RE, Klempner MS. Characterization of the neutrophil respiratory burst in atopy. J Allergy Clin Immunol 1988; 81;20-26.

65. Metzer S, Goldberg B, Lad P, Easton J. Superoxide generation and its modulation by adenosine in the neutrophils of subjects with asthma. J Allergy Clin Immunol 1989; 83:960-966.

66. Tanazawa H, Kurihara N, Hirata K, Takeda T. The role of free radicals in airway obstruction in asthmatic patients. Chest 1991; 100:1319-1322.

67. Loukides S, Buoros D, Papatheodorou G, Siafakas NM. The relationships among hydrogen peroxide in expired breathe condensate, airway inflammation, and asthma severity. Chest 2002; 121:338-346.

68. Nathan C. Neutrophils and immunity: challenges and opportunities. Nat Rev Immunol 2006; 6:173-182. doi: 10.1038/nri1785.

69. Uddin M, Watz H, Malmgren A, Pedersen F. (2019). NETopathic inflammation in chronic obstructive pulmonary disease and severe asthma. Front Immunol.

70. Tsan MF. Phorbol myristate acetate induced autotoxicity. J Cell Physiol 1980; 105(2):327-334.

71. Esaguy N, Aguas AP, Vilanova M, Silva MT. Activation of human neutrophils by phorbol ester decreases the cytoplasm compactness and the lactoferrin content of the granulocyte. J Leukoc Biol 1991; 50(5):444-452.

72. Takei H, Araki A, Watanabe H, Ichinose A, Sendo F. Rapid killing of human neutrophils by the potent activator phorbol 12myristate 13-acetate (PMA) accompanied by changes different from typical apoptosis or necrosis. J Leukoc Biol 1996; 59(2):229-240.

73. Brinkmann V, Reichard U, Goosman C, Fauler B, Uhlemann Y, Weiss DS, et al. Neutrophil extracellular traps kill bacteria. Science 2004; 303:1332-1535.

74. Yipp BG, Petri B, Salina D, Jenne CN, Scott BNV, Zbytnuik LD, Pittman K, Asaduzzaman $\mathrm{M}, \mathrm{Wu} \mathrm{K}$, et al. Infectioninduced NETosis is a dynamic process involving neutrophils multitasking in vivo. Nat Med 2012; 18:1386-1393.

75. Krishnamoorthy N, Douda DN, Brüggemann TR, Ricklefs I, Duvall MG, Abdulnour RE, Martinod K, Tarares L, Wang X, et al. National Heart, Lung Blood Institute Severe Asthma Research Program-3 Investigators. Neutrophil cytoplasts induce $\mathrm{T}_{\mathrm{H}} 17$ differentiation and skew inflammation towards neutrophilia in severe asthma. Sci Immunol 2018; 3(26): eaao4747.
76. Steiberg BE, Grinstein S. Unconventional roles of the NADPH oxidase: signaling, ion homeostasis, and cell death. Sci STKE 2007; 2007(379):e11.

77. Fuchs TA, Abed U, Goosmann C, et al. Novel cell death program leads to extracellular traps. J Cell Biol 2007; 176(2):231-241.

78. Brinkmann V, Zychlinsky A. Beneficial suicide: why neutrophils die to make NETs. Nat Rev Microbiol 2007; 5:577582.

79. Ueki S, Konno Y, Takada M, et al. Eosinophil extracellular trap cell death-derived DNA traps: their presence in secretions and functional attributes. J Allergy Clin Immunol 2016; 137(1):258-267.

80. Cheng OZ, Palaniyar N. NET balancing: a problem in inflammatory lung diseases. Front Immunol 2013; 4:1.

81. Jorch SK, Kubes P. An emerging role for neutrophil extracellular traps in noninfectious disease. Nat Med 2017; 23:279-287.

82. Kaplan MJ, Radic M. Neutrophil extracellular traps: doubleedged sword of innate immunity. J Immunol 201; 189:26892695.

83. Dwyer M, Shan Q, D'Ortona S, Maurer R, Mitchell R, Olesen $\mathrm{H}$, et al. Cystic fibrosis sputum DNA has NETosis characteristics and neutrophil extracellular trap release is regulated by macrophage migration-inhibitory factor. J Innate Immun 2014; 6:765-779.

84. Porto BN, Stein RT. Neutrophil extracellular trap in pulmonary diseases: too much of a good thing? Front Immunol 2016; $7: 311$.

85. Lefrancais E, Mallavia B, Zhuo H, Calfee CS, Looney MR. Maladaptive role of neutrophil extracellular traps in pathogeninduced lung injury. JCI Insight 2018; 3.

86. Faffarzadeh M, Juenemann C, Queisser MA, Lochnit G, Barreto G, Galuska SP, et al. Neutrophil extracellular traps directly induce epithelial and endothelial cell death: a predominant role of histones. PLoS ONE 2012; 7:e32366.

87. Narasaraju T, Yang E, Samy RP, Ng HH, Poh WP, Liew AA, et al. Excessive neutrophils and neutrophil extracellular traps contribute to acute lung injury of influenza pneumonitis. Am J Pathol 2011; 179:199-210.

88. Zou Y, Chen X, Xiao J, Bo Zhou D, Xiao Lu X, Li W, et al. Neutrophil extracellular traps promote lipopolysaccharideinduced airway inflammation and mucus hypersecretion in mice. Oncotarget 2018; 9:13276-13286.

89. Pedersen F, Marwitz S, Holz O, Kirten A, Bahmer T, Waschki $B$, et al. Neutrophil extracellular trap formation and extracellular DNA in sputum of stable COPD patients. Respir Med 2015; 109:1360-1362.

90. Pedersen F, Waschki B, Marwitz S, Goldman T, Kirsten A, Malmgren A, et al. Neutrophil extracellular trap formation is regulated by CXCR2 in COPD neutrophils. Eur Respir J. 2018; 51 .

91. Obermayer A, Stoiber W, Krautgartner WD, Klappacher M, Kofler B, Steinbacher P, et al. New aspects on the structure of neutrophil extracellular traps from chronic obstructive pulmonary disease and in vitro generation. PLoS ONE 2014; 9:e97784.

92. Grabcanovic-Musija F, Obermayer A, Stoiber W, Krautgartner WD, Steinbacher P, Winterberg N, et al. Neutrophil extracellular trap (NET) formation characterizes stable and exacerbated COPD and correlates with airflow limitation. Respir Med 2015; 16:59.

93. Pham DL, Ban GY, Kim SH, Shin YS, Ye YM, Chwae YJ, et al. Neutrophil autophagy and extracellular DNA traps 
contribute to airway inflammation in severe asthma. Clin Allergy 2017; 47:57-70.

94. Dicker AJ, Crichton MI, Pumphrey EG, Cassidy AJ, SuarezCuartin G, Sibila O, et al. Neutrophil extracellular traps are associated with disease severity and microbiota diversity in patients with chronic obstructive pulmonary disease. J Allergy Clin Immunol 2018; 141:117-127.

95. Toussaint M, Jackson D, Swieboda D, Guedan A, Tsourouktsoglou T-D, Ching YM, Radermecker C, Makrinioti $\mathrm{H}$, et al. Host DNA released by NETosis promotes rhinovirusinduced type- 2 allergic asthma exacerbations. Nature Medicine 2017; 23:681-691.

96. Bordon Y. The NET effect of respiratory viruses. Nat Rev Immunol 2017; 17:347.

97. Hoppenbrouwers T, Sultan AR, Abraham TE, Lemmens-den Toom NA, Hansenova Manaskova S, van Cappellen WA, et al. Staphylococcal protein A is a key factor in neutrophil extracellular trap formation. Front Immunol 2018; 9:165.

98. McCormick A, Heesenmann L, Wagener J, Marcos V, Hartl D, Loeffler J, et al. NETs formed by human neutrophils inhibit growth of the pathogenic mold Aspergillus fumigatus. Microbes Infect 2010; 12(12-13):928-936.

99. Rohm M, Grimm MJ, D’Auria AC, Almyroudis NG, Segal BH, Urban CF. NADPH oxidase promotes neutrophil extracellular trap formation in pulmonary aspergillosis. Infect Immun 2014; 82:1766-1777.

100. Lachowicz-Scroggins ME, Dunican EM, Charbit AR, Raymond W, Looney MR, Peters MC, Gordon ED, Woodruff PG, et al. Extracellular DNA, neutrophil extracellular traps, and inflammasome activation in severe asthma. Am J Respir Crit Care Med 2019; 199(9).

101. Rouvier E, Luciani MF, Mattéi MG, Denoit F, Golstein P. CTLA-8, cloned from activated $\mathrm{T}$ cell, bearing AU-rich messenger RNA instability sequences, homologous to a herpes virus saimari gene. J Immunol 1993; 150:5445-5456.

102. Yao Z, Maraskovsky E, Spriggs MK, Cohen JI, Armitage RJ, Alderson MR. Herpesvirus saimari open reading frame 14, a protein encoded by T lymphotropic herpes virus, binds to MHC class II molecules and stimulates $\mathrm{T}$ cell proliferation. J Immunol 1996; 156:3260-3266.

103. Yao Z, Fanslow WC, Seldin MF, Rousseau AM, Painter SL, Comeau MR, Cohen JI, Spriggs MK. Herpes saimari encodes a new cytokine, IL-17, which binds to a novel cytokine receptor. Immunity 1995; 3:811-821.

104. Moseley TA, Haudenschild DR, Rose L, Reddi AH. Interleukin-17 family and IL-17 receptors. Cytokine Growth Factor Rev 2003; 14:155-174.

105. Aggarwal S, Gurney AL. IL-17: prototype member of an emerging cytokine family. J Leukoc Biol 2002; 71(1):1-8.

106. Gaffen SL. Biology of recently discovered cytokines: interleukin-17 - a unique inflammatory cytokine with roles in bone biology and arthritis. Arthritis Res Ther 2004; 6(6):240247.

107. Kolls JK, Lindén A. Interleukin-17 family members and inflammation. Immunity 2004; 21:467-476.

108. Lee J, Ho WH, Maruoka M, Corpuz RT, Baldwin DT, Foster JS, et al. IL-17E, a novel proinflammatory ligand for the IL-17 receptor homolog IL-17Rh1. J Biol Chem 2001; 276:16601664.

109. Weaver CT, Hatton RD, Mangan PR, Harrington LE. IL-17 family cytokines and the expanding diversity of effector T cell lineages. Annu Rev Immunol 2007; 25:821-852.

110. Hammad H, Lambrecht BN. Barrier epithelial cell and control of type 2 immunity. Immunity 2015; 43:29-40.
111. Chung S, Dong C. A novel heterodimeric cytokine consisting of IL-17 and IL-17F regulates inflammatory responses. Cell Res 2007; 17:435-440.

112. Gaffen S. Structure and signaling of the IL-17 receptor family. Nat Immunol 2009; 9(8):556-567.

113. Kuestner RE, Taft DW, Haran A, Bradt Cs, Blender T, Lum K, Harder B, Okada S, et al. Identification of the IL-17 receptor related molecule IL-17RC as the receptor for IL-17F. J Immunol 2007; 179:5462-5473.

114. Lubbert E, Joosten LA, Oppers B, van den Bersselaar L, Coenen-de Roo CJ, et al. IL-1-independent role of IL-17 in synovial inflammation and joint destruction during collageninduced arthritis. J Immunol 2001; 167:1004-1013.

115. Metawi S, Abbas D, Kamal M, Ibrahim M. Serum and synovial fluid levels of interleukin-17 in correlation with disease activity in patients with RA. Clin Rheumatol 2011; 30:1201-1207.

116. Park J, Park M, Lee S, Oh H, Lim M, Cho W, et al. TWEAK promotes the production of interleukin-17 in rheumatoid arthritis. Cytokine 212; 60:143-149.

117. Robert M, Miossec P. IL-17 in rheumatoid arthritis and precision medicine: from synovitis expression to circulating bioactive levels. Front Med (Luasanne) 2018; 5:364.

118. Arican OAM, Sasmaz S, Ciragil P. Serum levels of TNF-alpha, IFN-gamma, IL-6, IL-8, IL-12, IL-17, and IL-18 in patients with active psoriasis and correlation with disease severity. Mediators Inflamm 2005; 2005(5):273-279.

119. Martin DA, Toune JE, Kricorian G, Klekotka P, Gudjonsson JE, Krueger JG, et al. The emerging role of IL-17 in the pathogenesis of psoriasis: preclinical and clinical findings. $\mathrm{J}$ Invest Dermatol 2013; 133(1):17-26.

120. Papp KA, Leonardi C, Menter A, Ortonne J-P, Kruger JG, Kricorian G, Aras G, et al. Brodalumab, an anti-interleukin-17receptor antibody for psoriasis. N Engl J Med 2012; 366(13):1181-1189.

121. Park SJ, Lee YC. Interleukin-17 regulation: an attractive therapeutic approach for asthma. Respir Res 2010; 11:78.

122. Syabbalo N. Mechanisms of IL-17 in the pathogenesis of neutrophilic asthma. J Pulm Med Respir Res 2020; 6:032.

123. Park H, Li Z, Yang XO, Chang SH, Nurieva R, Wang T, Hood $\mathrm{L}$, et al. A distinct lineage of $\mathrm{CD} 4 \mathrm{~T}$ cells regulates tissue inflammation by producing interleukin 17. Nat Immunol 2005; 6(11):1133-1141.

124. Langrish CL, Chen Y, Blumenschein WM, Matton J, Basham B, Sedgwick JD, McClahanan T, et al. IL-23 dives a pathogenic population that induces autoimmune inflammation. J Exp Med 2005; 201(2):233-240.

125. Ivanov S, Lindén A. Interleukin-17 as a drug target in human disease. Trends Pharmacol Sci 2009; 30:95-103.

126. Michel ML, Mendes-da-Cruz D, Keller AC, Lochner M, Schneider E, Dy M, et al. Critical role of ROR-gammat in a new thymic pathway leading to IL-17-producing invariant NKT cell differentiation. Proc Natl Acad Sci USA 2008; 105:1984518850 .

127. Zhao Y, Zhao Y, Yang J, Gao YD. Altered expression of T cell (Th)1, Th2, and Th17 cytokines in CD8+ and $\mathrm{Y} \delta \mathrm{T}$ cells in patients with allergic asthma. J Asthma 2011; 48:429-436.

128. Roark CL, Simonian PL, Fontenot AP, Born WK, O’Brien RL. Gammadelta T cells: an important source of IL-17. Curr Opin Immunol 2008; 20:353-357.

129. Rachitskaya AV, Hansen AM, Horai R, Li Z, Villasmil R, Luger D, Nussenblast RB, Caspi RR. Cutting edge: NKT cells constitutively express IL-23 receptor and RORgammat and rapidly produce IL-17 upon receptor ligation in an IL-6-induced fashion. J Immunol 2008; 180:5167-5171. 
130. Coquet JM, Chakravarti S, Kyparissoudis K, McNab FW, Pitt LA, McKenzie BS, Berzins SP, et al. Diverse cytokine production by NTK cell subsets and identification of an IL-17producing D4- NK1.1-NKT cell population. Proc Natl Acad Sci USA 2008; 105:11287-11292.

131. Takatori H, Kunno Y, Watford WT, Tato CM, Weiss G, Ivanov II, Littman DR, O'Shea JJ. Lymphoid tissue inducer-like cells are an innate source of IL-17 and IL-22. J Exp Med 2009; 206:35-41.

132. Cua DJ, Tato CM. Innate IL-17 producing cells: the sentinel of the immune system. Nat Rev Immunol 2010; 10:479-489.

133. Molet S, Hamid Q, Davoine F, Nutku E, Taha R, Pagé N, Olivenstein R, Elias J, Chakir J. IL-17 is increased in asthmatic airways and induces human bronchial fibroblasts to produce cytokines. J Allergy Clin Immunol 2001; 108:430-438.

134. Barczyk A, Pierzchala W, Sozañska E. Interleukin-17 in sputum correlates with airway hyperresponsiveness to methacholine. Respir Med 2003; 97:726-733.

135. Sun Y-C, Zhou Q-T, Yao W-Z. Sputum interleukin-17 is increased and associated with airway neutrophilia in patients with severe asthma. Chin Med J (Engl) 2005; 118:953-956.

136. Bullens DM, Truyen E, Coteur L, Dilissen E, Hellings PW, Dupont LJ, Ceuppens JL. IL-17 mRNA in sputum of asthmatic patients: linking $\mathrm{T}$ cell driven inflammation and granulocytic influx? Respir Res 2006; 7:135.

137. AL-Ramli W, Préfontaine D, Chouiali F, Martin JG, Olinenstein R, Lemière C, Hamid Q. T(H)17-associated cytokines (IL-17A and IL-17F) in severe asthma. J Allergy Clin Immunol 2009; 123:1185-1187.

138. Doe C, Bafedhel M, Siddiqui S, Desai D, Mistry V, Rugman P, McCormick M, Woods J, May R, Sleeman NA, et al. Expression of T helper 17-associated cytokines IL-17A and IL17F in asthma and COPD. Chest 2010; 138:1140-1147.

139. Agache I, Ciobanu S, Agache C. Anghel M. Increased serum IL-17 is an independent risk factor for severe asthma. Respir Res 2010; 1131-1137.

140. Wang YH, Voo KS, Liu B, Chen CY, Uygungil B, Spoede W, Bernstein JA, Huston DP, Liu YJ. A novel subset of CD4(+) $\mathrm{T}(\mathrm{H})$ memory/effector cells that produce inflammatory IL-17 cytokines and promotes exacerbations of chronic allergic asthma. J Exp Allergy 2010; 207:2479-2491.

141. Cosmi L, Maggi L, Santarlasci V, Capone M, Cardilicchia E, Frosali F, Querci V, Angeli R, Matucci A, Fambrini M, et al. Identification of a novel subset of human circulating memory CD4(+) T cell that produce both IL-17A and IL-4. J Allergy Clin Immunol 2010; 125:222-230.e1-e4.

142. Chien JW, Lin CY, Yang KD, Kao JK, Tsai YG. Increased IL17A secreting CD4+ cells, serum IL-17 levels and nitric oxide are correlated with childhood asthma severity. Clin Exp Allergy 2013; 43:1018-1026.

143. Irvin C, Zafar I, Good J, Rollins D, Christianson C, Gorska MM, Martin RJ, Alam R. Increased frequency of dual positive TH2/TH17 cells in bronchoalveolar lavage fluid characterizes a population of patients with severe asthma. Allergy Clin Immunol 2013; 132:1194-1204.e2.

144. Kim HY, Lee HJ, Chang Y-J, Pichavant M, Shore SA, Fitgerald $\mathrm{KA}$, Iwakura $\mathrm{Y}$, Israel $\mathrm{E}$, et al. Interleukin-17 producing innate lymphoid cells and the NLRP3 inflammasome facilitate obesity-associated airway hyperreactivity. Nat Med 2014; 20:54-61.

145. Onishi RM, Gaffen SL. Interleukin-17 and its target genes: mechanisms of interleukin-17 function in disease. Immunol 2010; 129(3):311-321.
146. Xu S, Cao X. Interleukin-17 and its expanding biological functions. Cell Mol Immunol 2010; 7:164-174.

147. Weaver CT, Hatton RD, Mangan PR, Harrington LE. IL-17 family cytokines and expanding diversity of effector $\mathrm{T}$ cell lineages. Annu Rev Immunol 2007; 25:821-852.

148. Shen F, Gaffen SL. Structure-function relationships in the IL17 receptor: implications for signal transductions and therapy. Cytokines 2008; 41:92-104.

149. Fossiez F, Djossou O, Chomarat P, Flores-Romo L, Ait-Yahia $\mathrm{S}$, Maat $\mathrm{C}$, et al. $\mathrm{T}$ cell interleukin-17 induces stromal cells to produce pro-inflammatory and hematopoietic cytokines. J Exp Med 1996; 163:2593-2603.

150. Laan M, Prause O, Miyamoto M, Sjöstrand M, Hytönen AM, Keneko T, et al. A role of GM-CSF in the accumulation of neutrophils in the airways caused by IL-17 and TNF- $\alpha$. Eur Respir J 2003; 21:387-393.

151. Lindén A. Interleukin-17 and airway remodelling. Pulm Pharmacol Ther 2006; 19(1):47-50.

152. Molet S, Hamid Q, Davoine F, Nutku E, Taha R, Page N, Olivenstein R, Elias J, Chakir J. IL-17 is increased in asthmatic airways and induces human bronchial fibroblasts to produce cytokines. J Allergy Clin Immunol 2001; 108(3):430-438.

153. Bellini A, Marini MA, Bianchetti L, Barczyk M, Schmidt M, Matoli S. Interleukin (IL)-4, IL-13, and IL-17 differentially affect the profibrotic and proinflammatory functions of fibroblasts from asthmatic patients. Mucosal Immunol 2012; 5:140-149.

154. Al-Muhsen S, Letuve S, Vazquez-Tello A, Pureza MA, AlJahdali H, Bahammam AS, Hamid Q, Halwani R. Th17 cytokines induce profibotic cytokines release from human eosinophils. Respir Res 2013; 14:34.

155. Chakir J, Shannon J, Molet S, Fukakusa M, Elias J, Laviolette M, Boulet L-P, Hamid Q. Airway remodeling-associated mediators in moderate to severe asthma: effect of steroids on TGF- $\beta$, IL-17, and type 1 and III collagen expression. J Allergy Clin Immunol 2003; 111:1293-1298.

156. Chang Y, Al-Alwan L, Risse P-A, Halayko AJ, Martin JG, Baglole CJ, Eidelman DH, Hamid Q. Th17-associated cytokines promote human airway smooth muscle cell proliferation. FASEB J 2012; 26:5152-5160.

157. Al-Alwan LA, Chang Y, Baglole CJ, Risse PA-, Halayko AJ, Martin JG, Eildelman DH, Hamid Q. Autocrine-regulated airway smooth muscle cell migration on IL-17-induced growthrelated oncogenes. J Allergy Clin Immunol 2012; 130:977985.e6.

158. Chang Y, Al-Alwan L, Risse P-A, Rousseau S, Halayko AJ, Martin JG, Hamid Q. TH17 cytokines induce human airway muscle cell migration. J Allergy Clin Immunol 2011; 127:10461053.e1-e2.

159. Kudo M, Melton AC, Chen C, Angler MB, Huang KE, Wang Y, Berstein X, Li JT, et al. IL-17A produced by $\alpha \beta$ T cells drives airway hyper-responsiveness in mice and enhances mouse and human airway smooth muscle contraction. Nat Med 2012; 2012; 18:547-554.

160. Lu S, Li H, Gao R, Xu F, Wang Q, Lu G, Xia D, Zhou J. IL-17, but not IL-17F, is indispensible for airway vascular remodeling induced by exaggerated Th17 cell responses in prolonged ovalbumin-challenged mice. J Immunol 2015; 194(8):35573566.

161. Chen Y, Thai P, Zhao Y-H, Ho Y-S, DeSouza MM, Wu R. Stimulation of airway mucin gene expression by interleukin (IL)-17 through IL-6 paracrine/autocrine loop. J Biol Chem $2003 ; 278: 17036-17043$. 
162. Fujisawa T, Velicho S, Thai P, Huang LY, Huang F, Wu R. Regulation of airway MUC5AC expression by IL-1beta and IL17A; the NF-kappa paradigm. J Immunol 2009; 183:62366243.

163. Vazquez-Tello A, Halwani R, Hamid Q, Al-Muhsen S. Glucocorticoid receptor-beta upregulation and steroid resistance induced by IL-17 and IL-23 cytokine stimulation in peripheral mononuclear cells. J Clin Immunol 2013; 33:466478.

164. Nanzer AM, Chambers ES, Ryanna K, Richards DF, Black C, Timms PM, Martineau AR, Griffths CJ, Corrigan CJ, Hawrylowicz CM. Enhanced production of IL-17A in patients with severe asthma is inhibited by $1 \alpha, 25$-dyhydoxyvitamin D3 in a glucocorticoid-independent fashion. J Allergy Clin Immunol 2013; 132:297-304.e3.

165. Nair P, Gaga M, Zevas E, Alagha K, Hargreave FE, O’Byrne $\mathrm{PM}$, et al. Safety and efficacy of CXCR2 antagonist in patients with severe asthma and sputum neutrophilia: a randomized placebo-controlled clinical trial. Clin Exp Allergy 2013; 42:1097-1103.

166. O'Byrne PM, Metev H, Puu M, et al. Efficacy and safety of a CXCR2 antagonist, AZD5069, in patients with uncontrolled persistent asthma: a randomized, double-blind, placebocontrolled trial. Lancet Med 2016; 4:797-806.

167. Busse WW, Holgate S, Kerwin E, Chon Y, Feng J, Lin J, et al. Randomized, double-blind, placebo-controlled study of brodalumab, a human anti-IL-17 receptor monoclonal antibody, in moderate to severe asthma. Am J Respir Crit Care Med 2013; 188(11):1294-1302.

168. Kirsten A, Watz H, Pedersen F, Holz O, Smith R, Bruin G, et al. The anti-IL-17A antibody secukinumab does not attenuate ozone-induced airway neutrophilia in healthy volunteers. Eur Respir J 2013; 41:239-241.

169. Foulkes A. Brodalumab in psoriasis: evidence to date and clinical potential. Drugs Context 2019; 8:212570.

170. Rich P, Sigurgeirsson B, Thaci D, et al. Secukinumab induction and maintenance therapy in moderate-to-severe plaque psoriasis: a randomized, double-blind, placebo-controlled, phase ii regimen-finding study. $\mathrm{Br}$ J Dermatol 2013; 168(2):402-411.

171. Piscitelli SC, Danzinger LH, Rodvold KA. Clarithromycin and azithromycin: new macrolide antibiotics. Clin Pharm 1992; 11(2):137-152.

172. Retsema J, Girard A, Schelkly W, Manousos M, Anderson M, Bright $\mathrm{G}$, et al. Spectrum and mode of action of azithromycin (CP-62,993), a new 15-membered-ring macrolide with improved potency against gram-negative organisms. Antimicrob Agents Chemother 1987; 31(12):1939-1947.

173. Tenson T, Lovmar M, Ehrenberg M. The mechanism of action of macrolides, lincosamides and streptogramin $\mathrm{B}$ reveals the nascent peptide exit path in the ribosome. J Mol Biol 2003; 330(5):1005-1014.

174. Zuckerman JM. Macrolides and ketolides: azithromycin, clarithromycin, telithromycin. Infect Dis Clin North Am 2004; 18(3):621-649.

175. Plewig G, Schopf E. Anti-inflammatory effects of antimicrobial agents: an in vivo study. J Invest Dermatol 1975; 65(6):532536.

176. Shinkai M, Henke MO, Rubin BK. Macrolide antibiotics as immunomodulatory medications: proposed mechanisms of action. Pharmacol Ther 2008; 117:393-405.

177. Cramer CL, Patterson A, Alchakaki A, Soubani CL, Immunomodulatory indication of azithromycin in respiratory disease: a concise review for the clinician. Postgrad Med 2017; 129:493-499.

178. Zimmermann P, Ziesenitz VC, Curtis N, Ritz N. The immunomodulatory effects of macrolides - a systemic review of the underlying mechanisms. Front Immunol 2018.

179. Cigana C, Assael BM, Melotti P. Azithromycin selectively reduces necrosis factor alpha levels in cystic fibrosis airway epithelial cells. Antimicrob Agents Chemother 2007; 51:975981.

180. Piacentini GL, Peroni DG, Bodini A, Pigozzi R, Costella S, Loiacono A, et al. Azithromycin reduces bronchial hyperresponsiveness and neutrophilic airway inflammation in asthmatic children: a preliminary report. Allergy Asthma Proc 2007; 28:194-198.

181. He J, Zhu N, Chen X. Clinical impacts of azithromycin on lung function and cytokines for asthmatic patients. JMS 2009; 36(6):719-722.

182. Fonseca-Aten M, Okada PJ, Bowlware KL, Chavez-Bueno S, Mejias A, Rio AM, et al. Effect of clarithromycin on cytokines and chemokines in children with an exacerbation of recurrent wheezing: a double-blind, randomized, placebo-controlled trial. Ann Allergy Asthma Immunol 2006; 97(4):457-463.

183. Kamoi H, Kurihar N, Fujiwara H, Hirata K, Takeda T. The macrolide antibacterial roxithromycin reduces bronchial hyperresponsiveness and superoxide inion production by polymorphonuclear leukocytes in patients with asthma. J Asthma 1995; 32(3):191-197.

184. Crosbie PAJ, Woodhead M. Long-term macrolide therapy in chronic inflammatory airway diseases. Eur Respir J 2004; 24:822-833.

185. Sun J, Li Y. Long-term, low-dose macrolide antibiotic treatment in pediatric chronic airway diseases. Ped Res 2021.

186. Koyama H, Geddes DM. Erythromycin and diffuse panbrochiolitis. Thorax 1997; 52:15-18.

187. Southern KW, Barker PM, Solis-Moya A, Patel L. Macrolide antibiotics for cystic fibrosis. Cochrane Database Syst Rev 2012; 11:Cd002203.

188. Wang D, Fu W, Dai J. Meta-analysis of macrolide maintenance therapy for prevention of disease exacerbations in patients with noncystic fibrosis bronchiectasis. Medicine 2019; 98:e15285.

189. Meyer KC, et al. An International ISHLT/ATS/ERS clinical practice guideline: diagnosis and management of bronchiolitis obliterans syndrome. Eur Respir J 2014; 44:1479-1503.

190. Kingah PL, Muma G, Soubani A. Azithromycin improves lung function in patients with post-lung transplantation bronchiolitis obliterans syndrome: a meta-analysis. Clin Transplant 2014; 28:906-910.

191. Cui Y, Luo L, Li C, Chen P, Chen Y. Long-term macrolide treatment for the prevention of acute exacerbations of COPD: a systemic review and meta-analysis. Int $\mathrm{J}$ Chron Obstruct Pulmon Dis 2018; 13:3813-3829.

192. Itkin IH, Menzel ML. The use of macrolide antibiotic substances in the treatment of asthma. J Allergy 1970; 45:146162.

193. Gibson PG. Macrolides for yet another chronic airway disease. Thorax 2012.

194. Kew KM, Undela K, Kotortsi I, Ferrara G. Macrolides for chronic asthma. Cochrane Database Syt Rev 20151 Cd002997.

195. Smith D, et al. The British Thoracic Society guideline for the use of long-term macrolides in adults with respiratory disease. Thorax 2020; 75:370-404.

196. Simpson J, Powell H, Boyle MJ, Scott RJ, Gibson PG. Clarithromycin targets neutrophilic airway inflammation in 
refractory asthma. Am J Respir Crit Care Med 2008; 177(2):148-155.

197. Brusselle GG, Vandertichele C, Jorgens P, Deman R, Slabbynck H, Ringoet V, et al. Azithromycin for prevention of exacerbations in severe asthma (AZISAST): a multicentre randomised double-blind placebo-controlled trial. Thorax 2013; 68(4):322-329.

198. Gibson PG, Yang IA, Upham JW, Reynolds PN, Hodge S, James AL, Jenkins C, Peters MJ, et al. Effect of azithromycin on asthma exacerbations and quality of life in adults with persistent uncontrolled asthma (AMAZES): a randomized, double-blind, placebo-controlled trial. Lancet 2017; 390(10095):659-668.

199. Johnson SL, Blasi F, Black PN, Martin RJ, Farrell DJ, Nieman RB. The effect of telithromycin in acute exacerbations of asthma. N Engl J Med 2006; 354:1589-1600.

200. Johnston SL, Szigeti M, Cross M, Brightling C, Chaudhuri R, Harrison T, Mansur A, Robison L, Sattar Z, et al. Azthromycin for acute exacerbaions of asthma: The AZALEA randomized clinical trial. JAMA Int Med 2016; 176(11):1630-1637.

201. Cox G, Thomson NC, Rubin AS, et al. Asthma control during the year after bronchial thermoplasty. N Engl J Med 2007; 356:1327-1337.

202. Thomson NC, Bicknell S, Chaudhuri R. Bronchial thermoplasty: a new therapeutic option for severe asthma. Curr Opin Allergy Clin Immunol 2012; 12(3):241-248.

203. Laxmanan B, Hogarth DK. Bronchial thermoplasty in asthma: current perspectives. J Asthma Allergy 2015; 8:39-49.

204. Thomson NC, Chanez P. How effective is bronchial thermoplasty for severe asthma in practice? Eur Respir J, 2017; 50:1701140.

205. Thomson NC. Bronchial thermoplasty as a treatment for severe asthma: controversies, progress and uncertainties. Exp Rev Respir Med 2018; 12(4):269-282.

206. Bonta PI, Chanez P, Annema JT, Shah PI, Niven R. Bronchial thermoplasty in severe asthma: best practice recommendations from an expert panel. Respiration 2018; 95:289-300.

207. Tan LD, Yoneda KY, Louie S, Hogarth DK, Castro M. Bronchial thermoplasty: A decade experience: state of the art. J Allergy Clin Immunol in Pract 2019; 7(1):71-80.

208. Thomson NC. Recent developments in bronchial thermoplasty for severe asthma. J Asthma Allergy 2019; 12:375-387.

209. Syabbalo N. Bronchial thermoplasty in the treatment of severe asthma. J Pulmonol Res Rep 2020; 2(2):3-9.

210. Dombret M-C, Alagha K, Boulet LP, Brillet MY, Joos G, Lavilette M, Louis R, Rochat T, Soccal P, Aubier M, Chanez P. Bronchial thermoplasty: a new therapeutic option for the treatment of severe, uncontrolled asthma in adults. Eur Respir Rev 2014; 23:510-518.

211. Foreman C. Alair Bronchial Thermoplasty System: Alair Catheter and AR Controller.
212. Pretolani M, Dombret MC, Thabut G, Knap D, Hamidi F, Debray MP, et al. Reduction of airway smooth muscle mass by bronchial thermoplasty in patients with severe asthma. Am J Respir Crit Care Med 2014; 190:1452-1454.

213. Chakir J, Haj-salem I, Gras D, et al. Effect of bronchial thermoplasty on airway smooth muscle and collagen deposition in asthma. Ann Am Thorac Soc 2015; 12:1612-1618.

214. Pretolani M, Bergqvist A, Thabut G, et al. Effectiveness of bronchial thermoplasty in patients with severe refractory asthma: clinical and histological correlations. J Allergy Clin Immunol 2017; 139(4):1176-1185.

215. Facciolongo N, Di Stefano A, Pietrini V, et al. Nerve ablation after bronchial thermoplasty and sustained improvement in severe asthma. BMC Pulm Med 2018; 18(1):29.

216. Haj Salem I, Gras D, Joubert P, et al. Persistent reduction in mucin production after bronchial thermoplasty in severe asthma. Am J Respir Crit Care Med 2019; 199(4):536-538.

217. Fang L, Li J, Papakonstantinou E, Karakioulaki M, Sun Q, Schumann D, Tamm M, Stolz D, Roth M. Secreted heat shock proteins control airway remodeling: evidence from bronchial thermoplasty. J Allergy Clin Immunol 2021.

218. Papakonstantinou E, Koletsa T, Fang L, Roth M, Karakioulaki M, Savic S, Grize L, Tamm M, Stolz D. Bronchial thermoplasty in asthma: an exploratory histological evaluation in distinct asthma endotypes/phenotypes. Respir Res 2021; 22:186.

219. Parvord ID, Cox G, Thomson NC. Safety and efficacy of bronchial thermoplasty in symptomatic, severe asthma. Am J Respir Crit Care Med 2007; 176:1185-1191.

220. Castro M, Rubin AS, Laviolette M, et al. Effectiveness and safety of bronchial thermoplasty in the treatment of severe asthma: a multicenter, randomized, double-blind, shamcontrolled clinical trial. Am J Respir Crit Care Med 2010; 181:116-124.

221. Thomson NC, Rubin A, Niven R, et al. Long-term (5 years) safety of bronchial thermoplasty: Asthma Intervention Research (AIR) trial. BMC Pulm Med 2011; 11:8.

222. Pavord ID, Laviolette M, Thomson NC, et al. 5-year safety of bronchial thermoplasty demonstrated in patients with severe asthma. Research in Severe Asthma (RISA) trial. Am J Respir Crit Care Med 2011; 183:A6362.

223. Wechsler ME, Laviolette M, Rubin, et al. Bronchial thermoplasty: Long-term safety and effectiveness in patients with severe persistent asthma. J Allergy Clin Immunol 2013; 132: 132:1295-1302.

224. Chupp G, Laviolette M, Cohn L, et al. Long-term outcomes of bronchial thermoplasty in subjects with severe asthma: a comparison of 3-year follow-up results from two prospective multicenter studies. Eur Respir J, 2017; 50:1700017.

225. Chaudhuri R, Rubin A, Fiterman J, et al. Ten-year follow-up of subjects who received bronchial thermoplasty (BT) in 3 randomized controlled studies (BT10+). Eur Respir Soc Congr. 2019. Madrid. 
This work is licensed under Creative Commons Attribution 4.0 License

To Submit Your Article Click Here: Submit Manuscript

DOI: $10.31579 / 2693-2156 / 030$
Ready to submit your research? Choose Auctores and benefit from:

$>$ fast, convenient online submission

$>$ rigorous peer review by experienced research in your field

$>$ rapid publication on acceptance

$>$ authors retain copyrights

$>$ unique DOI for all articles

$>$ immediate, unrestricted online access

At Auctores, research is always in progress.

Learn more https://auctoresonline.org/journals/journal-of-thoracic-disease-andcardiothoracic-surgery 